\title{
Assessment of Trace Gas Emissions From Wild Fires in Different Vegetation Types in Northern Ghana: Implications for Global Warming
}

\author{
Nyadzi Emmanuel $^{1}$, Ezenwa I. S. Mathew ${ }^{2}$, Nyarko K. Benjamin ${ }^{3}$, A. A. Okhimamhe ${ }^{1}$, \\ Bagamsah T. Thomas ${ }^{4}$ \& Okelola O. Francis ${ }^{1}$ \\ ${ }^{1}$ WASCAL CC\&ALU, Federal University of Technology, Minna, Nigeria \\ ${ }^{2}$ Department of Soil Science, Federal University of Technology, Minna, Nigeria \\ ${ }^{3}$ Department of Geography and Regional Planning, University of Cape Coast, Cape Coast, Ghana \\ ${ }^{4}$ Maryland Department of Agriculture: 50 Harry S Truman Parkway Annapolis, MD 21401, USA \\ Correspondence:Nyadzi Emmanuel, WASCAL Coordinating Unit, Federal University of Technology, Minna, \\ Nigeria. Tel: +233266413676 . E-mail: enyadzi@yahoo.com
}

\author{
Received: February 8, 2015 Accepted: February 27, 2015 Online Published: March 26, 2015 \\ doi:10.5539/enrr.v5n2p37 URL: http://dx.doi.org/10.5539/enrr.v5n2p37
}

\begin{abstract}
Biomass burning in Northern Ghana is a major cause for concern because of its potential contribution to global warming, hence climate change. This study assessed the emission of trace gases from human activities in the Guinea savanna of Northern Ghana using the guidelines of the Intergovernmental Panel on Climate Change. Carbon content of biomass was determined from four different vegetation covers in the study area; namely, widely open savanna woodland, grass/herb with scattered trees, open savanna woodland and closed savanna woodland. Under each vegetation cover, five plots $(1 \mathrm{~m} \times 1 \mathrm{~m})$ were demarcated for the estimation of above-ground biomass density. Using the combustion furnace method, emitted carbon, methane and carbon monoxide were estimated. Results showed that the emitted methane $\left(\mathrm{CH}_{4}\right)$ and carbon monoxide $(\mathrm{CO})$ differed significantly $(\mathrm{p}<0.05)$ under all the vegetation types. The gases were in perfect correlation $(\mathrm{r}=1.00)$ with the quantity of above-ground biomass density and carbon released, with more $\mathrm{CO}$ being emitted. Emission of $\mathrm{CH} 4$ and $\mathrm{CO}$ per hectare of burnt area in the open savanna woodland category was the highest with 0.001719 ton and 0.045119 ton respectively. Over time, emission of these gases may increase their atmospheric concentration, causing major health problems. The contribution to global warming, thus climate change, may also become quite significant. This underscores the fact that existing flaws in the wild fire management policy of Ghana must be effectively dealt with and appropriately implemented with regular reviews to reduce the annual wild fires that are very rampant in Northern Ghana, especially during the dry season.
\end{abstract}

Keywords: Trace gas emission, global warming, biomass burning, wild fires, Guinea savanna

\section{Introduction}

One of the most debated and a researched issue is the increase in concentration of greenhouse gases into the atmosphere and its effect on global warming (Schils et al., 2008). Typically major land-use changes, particularly through widespread use of wild fires, contribute significantly to atmospheric greenhouse gas emissions (Shimada et al., 2000). Two major causes of bush fires have been generally recognized: natural and anthropogenic (Jones, 1979; Langaas, 1995). Most of these fires, whether accidental or deliberate, are assumed to be generated by humans during dry periods, which vary between ecosystems and climate zones (Jones, 1979; Korem, 1985). Elsewhere around the globe, wild fires occur regardless of season. Australia, for example, is prone to bushfires irrespective of the season. Summer and autumn seasons are, however, considered to be the vulnerable periods in southern Australia, while in the Northern Territory experiences most of its fires in winter and spring (Middelmann, 2007). Studies on annual spatial distributions of burnt areas across the United States have shown the seasonal peak of biomass burning generally occurring during June to August (Zhang \& Kondragunta, 2008). Africa has been called a 'fire continent' (Trollope \& Trollope, 1996) because of pervasive anthropogenic fires that burn the savanna vegetation annually (Mbow et al., 2000; Reid et al., 2000; Laris, 2002; Danthu et al., 2003). Farmers and pastoralists in Africa have developed traditional ways of avoiding the overwhelming nature of fire. In Senegal they practise early season grass burning because they find it safest and most beneficial (Bucini 
\& Lambin, 2002). 'Green flush' from perennial grasses and landscape protection from destructive fires is also considered to be the reason for early season burning (Mbow et al., 2000). Meanwhile, in Mali, the earliest burning is carried out to suppress the growth of unpalatable grasses that have no use for grazing (Laris, 2002). In the savannas of Ghana, bushfires, which are mostly man-made, are very common. These fires are typically grass fires and their intensity is usually lower than that of the forest fires (Bagamsah, 2005).

In tropical savanna woodland regions, the frequency of bush fires is on the increase, with the rise in population pressures and intensive use of rangeland. These ecosystems naturally consist of layers of grass interspersed with trees and shrubs, with an estimated area of about 1900 million hectares (Bolin et al., 1979). Some of the extensive uses of fires in these tropical regions include shifting cultivation and deforestation, and clearances of agricultural residue are some of the extensive uses of fire in the tropical regions (Crutzen \& Andreae, 1990; Hao et al., 1990). Biomass burning is a large source of atmospheric carbon and a variety of greenhouse and trace gases, aerosols and pollutants that may significantly influence climate and atmospheric chemistry, particularly in the tropics (Hao \& Liu, 1994; Rudolph et al., 1995; Andreae, 1997; Korontzi et al., 2003; van der Werf et al., 2010). Bush fires in the savanna region of African result mostly from human activities, and may produce as much as a third of the total emissions from biomass burning across the globe (Hao et al., 1990; Cahoon et al., 1992; Stott, 1994). In recent decades, the implication of this has become apparent as studies began to establish a link between biomass emissions and the global budgets of many radioactively and chemically active gases such as carbon dioxide, carbon monoxide, methane, nitrous oxide, tropospheric ozone, methyl chloride and elemental carbon particulate (Andreae, 1990; Hao \& Liu, 1994; Rudolph et al., 1995; Korontzi et al., 2003). Therefore, biomass burning is now recognized as a significant global source of emission contribution.

However, despite this recognition, uncertainties about emissions from non-energy sources (e.g. biomass burning, vegetation, soil, ocean, non-vehicle mobile sources) at the global level are considerable (IPCC, 2001). This makes the development of a complete emission inventory a vital contribution to the successful study of global atmospheric chemistry and climate change (Jain et al., 2006). At local, national and regional scales, these inventories are also critical as they contribute to the achievement of the ultimate objective of the United Nations Framework Convention on Climate Change (UNFCCC, 1992). In Ghana, an average of $68 \pm 4$ thousand $\mathrm{km}^{2}$ of land is burnt annually; of this, $37 \pm 2.6$ thousand $\mathrm{km}^{2}$ occur in the Northern region of Ghana. Approximately $53-$ $56 \%$ of the total annual burnt land across Ghana occurs in the Northern region, which constitutes $29 \%$ of total dry land-cover of the country (Kugbe, 2012). This study aims at assessing the emission levels of $\mathrm{CH}_{4}$ and $\mathrm{CO}$ from biomass burning in four different vegetation covers (based on the site level classification in Northern Ghana) and their implications for global warming.

\section{Materials and Methods}

\subsection{Description and Location of the Study Area}

This study was conducted in the Northern Region of Ghana (Figure 1), which has a population of about 2,468,557 (GSS, 2010). It lies within the Guinea Savanna Agro-Ecological Zone and forms part of the Volta Basin between the latitudes $8^{\circ} 30^{\prime} \mathrm{N}$ and $10^{\circ} 30^{\prime} \mathrm{N}$ and the longitudes $2^{\circ} 30^{\prime} \mathrm{W}$ and $0^{\circ} 00^{\prime} \mathrm{W}$ respectively. Characteristically, the area is characterized by two main seasons, wet and dry. The dry season starts in November and ends in April. The study site experiences a mono-modal rainfall pattern, which starts from May and ends in October. Within this period, rainfall peaks in August and September (Bagamsah, 2005). The mean monthly temperatures vary from about $36^{\circ} \mathrm{C}$ in March/April to $27^{\circ} \mathrm{C}$ in August. Relative humidity ranges between $20 \%$ and $85 \%$ (Cobbina et al., 2011). Approximately, $80 \%$ of the soils are upland soils developed in-situ from Voltaian sandstone and classified under the group of Lixisols (FAO, 1988). In general, the soils of the region have much lower organic matter content and nutrient status than those in the southern regions, thus the potential productivity of the soils of this zone may be regarded as being appreciably lower than that of the majority of the forest zone (Wills, 1962). The general vegetation of the study area is the mid-dry savanna type, with patches of dry woodland savanna and wet savanna (Menz and Bethke, 2000) that are classified as Guinea savanna (Lawson, 1985). Typically, the natural vegetation comprises a mix of tree (Daniellia oliveri, Lophira spp, Terminalia glaucescens, Guiera senegalensis, Combretum glutinosum, etc.) and grass (Andropogon spp, Cymbopogon spp, Pennisetum spp, and Settaria spp, Aristida stipoides, Pennisetum spp, and Hyparrhenia spp) species (Bagamsah, 2005). In terms of land use, northern Ghana is mostly utilized for agriculture and the typical crops cultivated include okra (Abelemoschus esculentus), groundnut (Arachis hypogea), tomato (Lycopersicion esculantum), pepper (Capsieum spp), sweet potato (Ipomoea batatas), guinea corn (Sorghum spp), maize (Zea Mays), cowpeas (Vigna spp), cassava (Manihot spp) and yam (Diascorea spp.). 


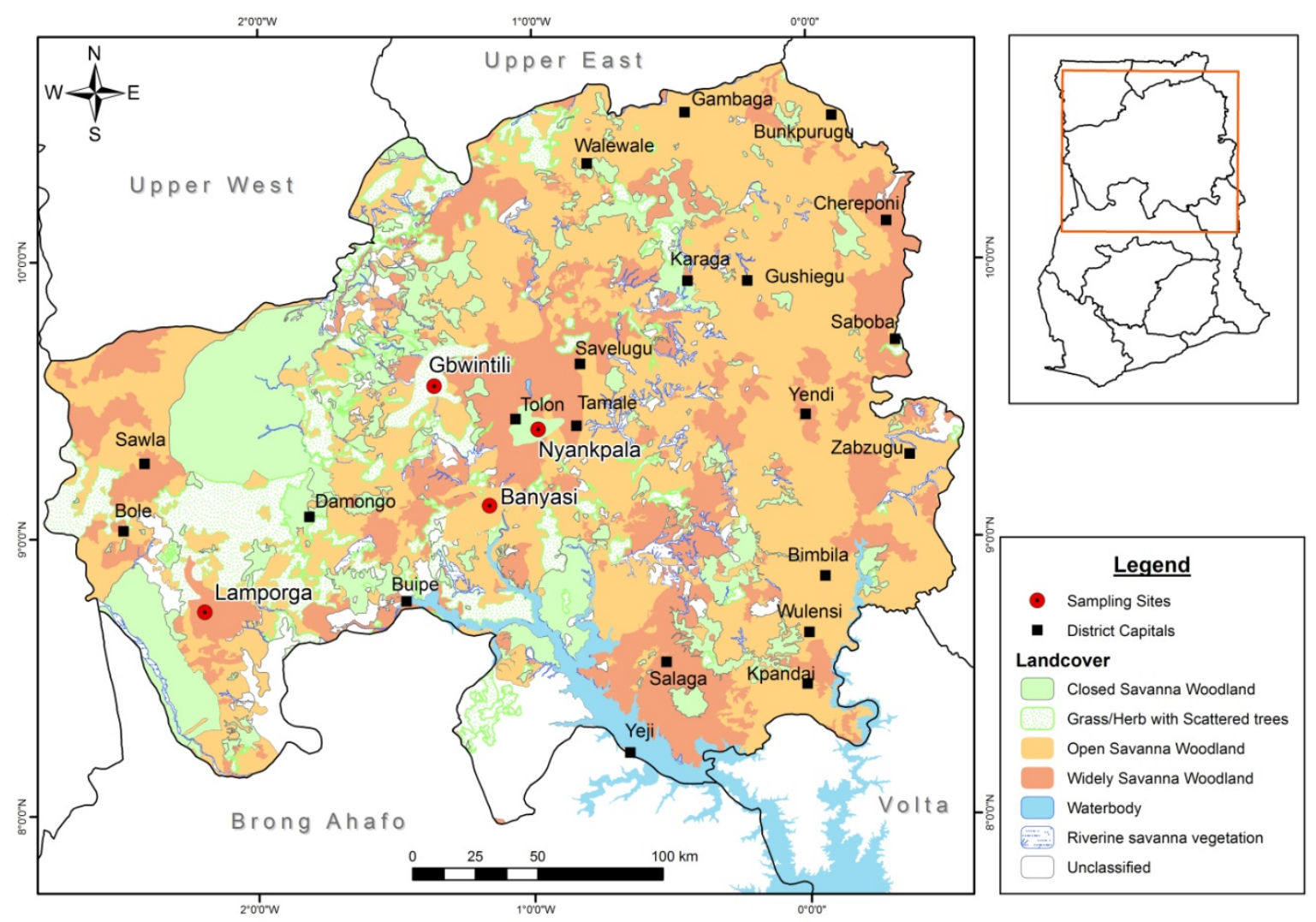

Figure 1. Map of the study area
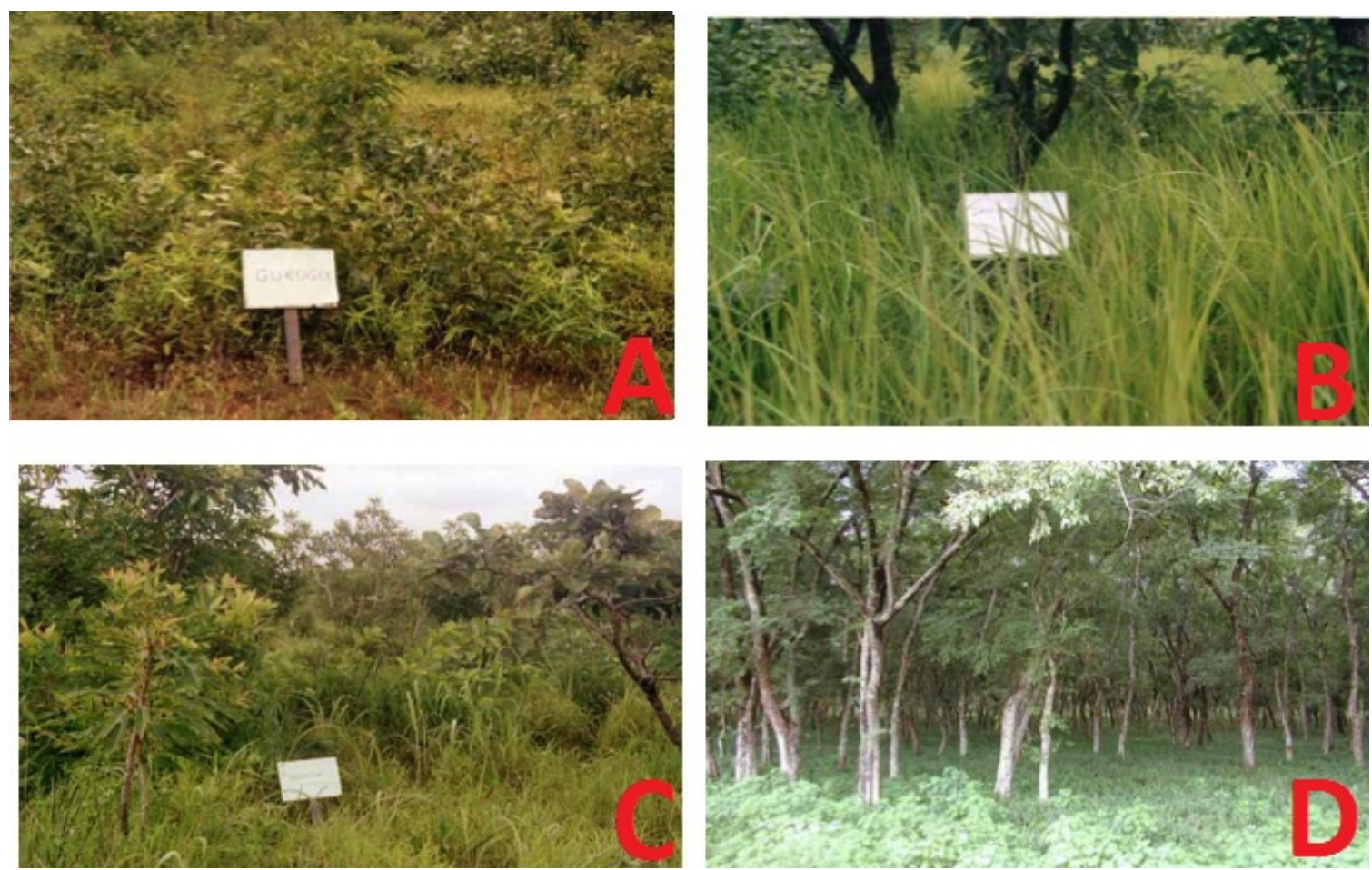

Figure 2. The four vegetation types as classified by Bagamsah (2005). (A) Widely Open Savanna Woodland. (B) Mixture of grass/herb fallow with scattered trees and shrubs. (C) Open savanna woodland vegetation dominated by shrubs (OSW). (D) Closed savanna woodland (CSW) 


\subsection{Site Selection and Experimental Layout}

Sampling was carried out within four different vegetation types (Figure 1); namely, widely open savanna woodland (WOSW), grass/herb with scattered trees (GHST), open savanna woodland (OSW) and closed savanna woodland (CSW), as classified by Bagamsah (2005). This classification was based on Dansereau's (1951) methodology for describing and recording vegetation on a structural basis. Figure 2 indicates the different vegetation types within which sampling were done. Using a GPS, a community was selected from each of the locations covered by the different vegetation types and they were used as experimental sites. The communities selected were Gwintili (GHST), Nyankpala (CSW), Banyasi (OSW) and Lamporga (WOSW). From each of these locations, samples of above-ground biomass (AGB) were collected from five randomly selected plots, each covering an area of $1 \mathrm{~m}^{2}$ (Figure 3).

\subsection{Determination of Carbon Content of Biomass Using the Combustion Furnace Method}

The combustion furnace method used in this study was adopted from Benscoter et al. (2011). The biomass was dried to a constant dry mass for four days at a temperature of $65^{\circ} \mathrm{C}$ and milled thoroughly in a Cyclone Mill. Each crucible was weighed $\left(\mathrm{W}_{1}\right)$, filled with $5 \mathrm{~g}$ of the milled biomass and weighed again $\left(\mathrm{W}_{2}\right)$. For ashing, the milled biomass and the crucibles were placed in a combusted muffle furnace carbolite at a temperature of $550{ }^{\circ} \mathrm{C}$ for four hours and weighed again $\left(\mathrm{W}_{3}\right)$. Then the proportion (\%) of organic carbon content was calculated using the following formulae:

$$
\begin{aligned}
& \% \text { Ash }=\frac{\mathrm{w} 3-\mathrm{W} 1}{\mathrm{~W} 2-\mathrm{W} 1} \times 100 \\
& \% \text { Organic matter }=100-\% \text { Ash } \\
& \% \text { Organic carbon }=\frac{\% \text { Organic matter }}{2}
\end{aligned}
$$

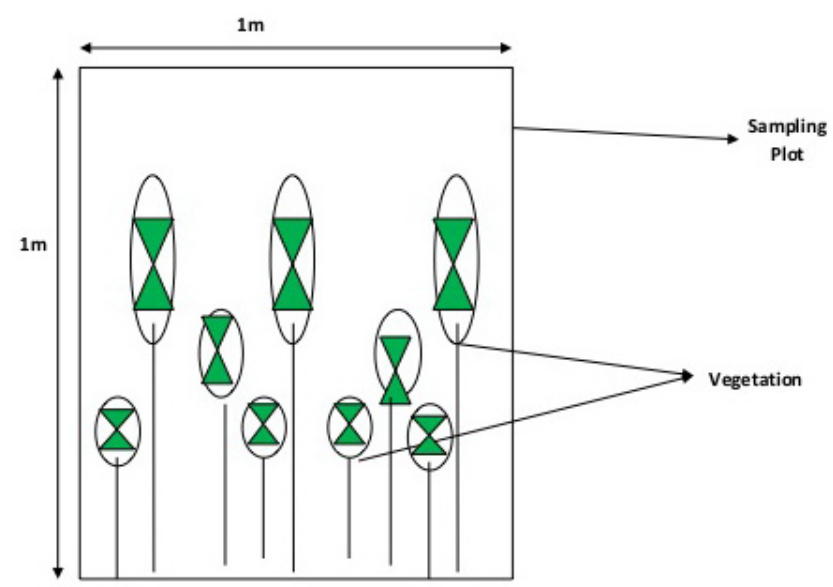

Figure 3. Schematic diagram showing experimental plot for sampling grass above-ground biomass

\subsection{Estimating the Amount of Carbon Release, Methane and Carbon Monoxide Emitted by Biomass Burning}

The carbon released from biomass burning in the study area was estimated using equations from the IPCC (1996) which involved the estimation of above-ground biomass density and carbon content in live and dead biomass. However, it must be noted that the estimated above-ground biomass density did not include standing trees; rather, the emphasis was on dried grass, litter, weeds and shrubs (Crutzen \& Andreae, 1990). The default values used in the calculations were adopted from Hao et al. (1990) and Menaut et al. (1991). After quantifying the released carbon from the burnt savanna vegetation, emissions of $\mathrm{CH}_{4}$ and $\mathrm{CO}$ were calculated and the emission ratios of $\mathrm{CH}_{4}$ (0.004) and CO (0.06) from Lacaux et al. (1993) were adopted. The estimated emission values were subjected to statistical analysis at a confidence level of $95 \%$. It is worthy of mention that the default values used in this study introduced some level of uncertainties into the estimation. However, the field and laboratory experiments carried out in the study reduced these uncertainties to an acceptable level. Additionally, the differences in biomass distribution across the study area made it difficult to accurately estimate the emitted carbon $\mathrm{CH}_{4}$ and $\mathrm{CO}$, so it is expected that there may be some degree of underestimation or overestimation of these values. 


\section{Result and Discussion}

\subsection{Grass Above-ground Biomass Density, Carbon Content and Total Carbon Emission}

The estimated above-ground biomass density for the selected vegetation classes varied significantly at $\mathrm{P}<0.05$. On the average, biomass density was highest on OSW with a density of $\sim 4.8 \mathrm{t} / \mathrm{ha}$. This result is comparable to those obtained by other authors. For example, Saarnak et al., (2003) and Bagamsah (2005) reported a range of 3.36-7.80 $\mathrm{t} / \mathrm{ha}$ and 2-3 t/ha respectively in northern Ghana; Shea et al. (1996) measured $3.7 \mathrm{t} / \mathrm{ha}$ in the savannas of South Africa, while Bourliére and Hardly (1983) reported 3.2-4.4 t/ ha in the savannas of Cote d'Ivoire. Figure 4 shows the estimated above-ground biomass density for the different vegetation types.

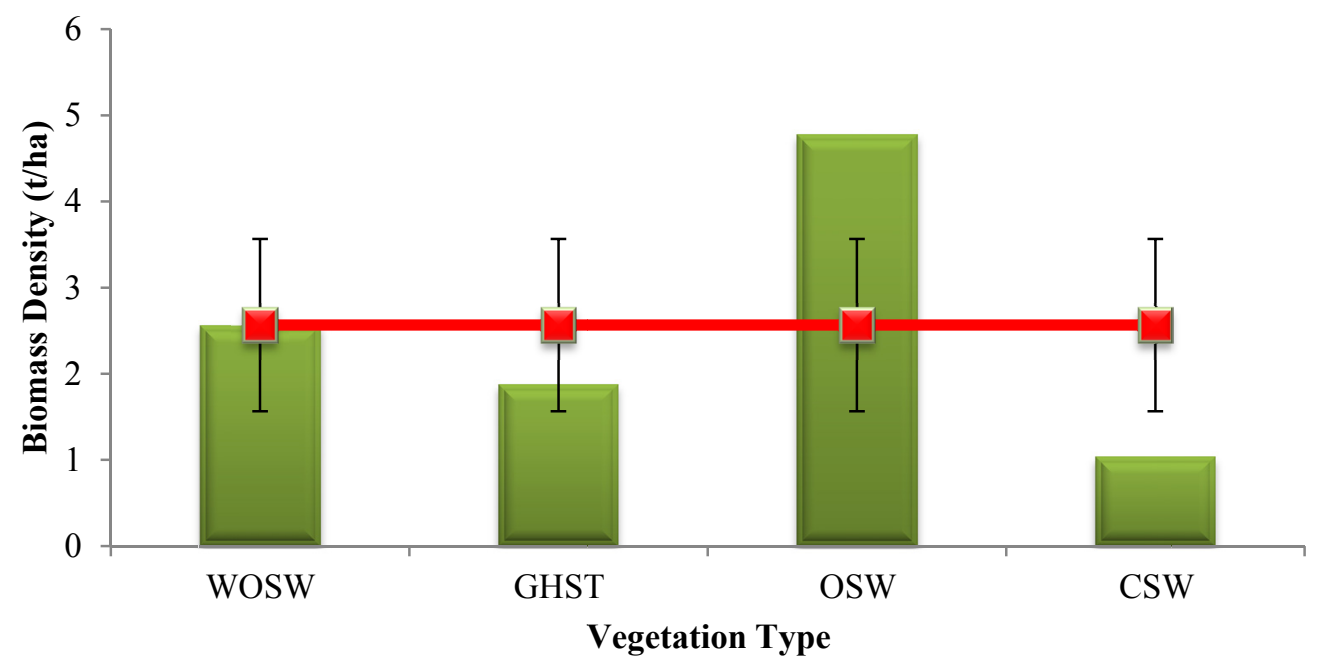

Figure 4. Estimated above-ground biomass density of grasses within the vegetation covers

Figure 5 shows that organic carbon content across the different vegetation types generally ranged from $29.3 \%$ to $45.5 \%$. On the average, GHST had the highest organic carbon content of $45.46 \%$, while the least was CSW with $29.28 \%$ organic carbon content. The difference in the measured carbon content of the vegetation types was significant at $\mathrm{P}<0.05$. Schlesinger (1991) noted that the carbon content of biomass is almost always found to be between $45 \%$ and $50 \%$. With the exception of GHST, the carbon content of the other vegetation types fell below this range. Recent studies have shown that these assumptions introduce some degree of error of $\sim 5 \%$ in forest carbon stock estimates (Martin \& Thomas 2011; Thomas \& Malczewski, 2007; Saner et al., 2012; Melson et al., 2011).

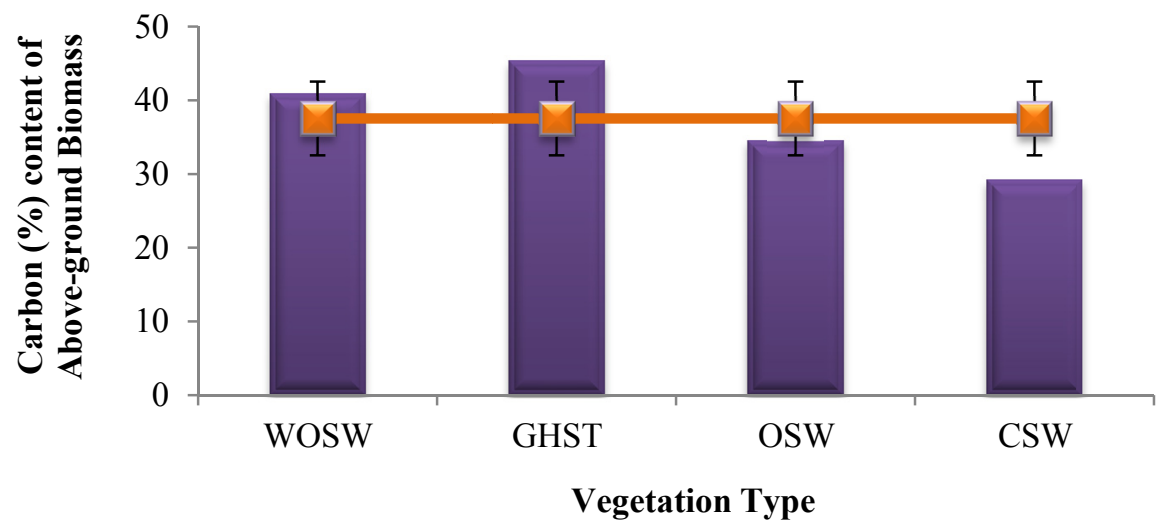

Figure 5. Estimated carbon content of grass above-ground biomass 
The total carbon released per hectare for the different vegetation types ranged from $\sim 0.000624 \mathrm{tC} / \mathrm{ha}$ to $\sim 0.398$ tC/ha. Figure 6 shows that carbon emissions from OSW, WOSW, GHST and CSW were $\sim 0.322 \mathrm{tC} / \mathrm{ha}, \sim 0.238$ $\mathrm{tC} / \mathrm{ha}, \sim 0.216 \mathrm{tC} / \mathrm{ha}$ and $\sim 0.050 \mathrm{tC} / \mathrm{ha}$ respectively. The carbons released from the four types of vegetation during burning were significantly different at $\mathrm{p}<0.05$.

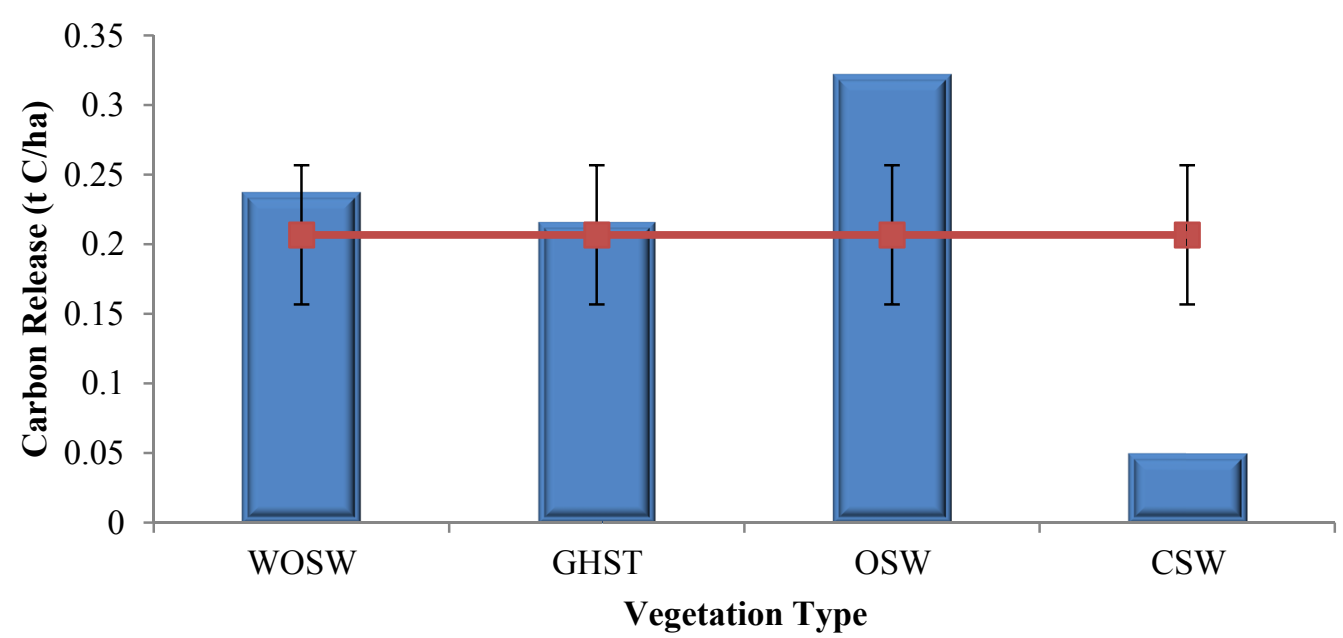

Figure 6. Total carbon emitted per hectare

Figures 5 and 6 clearly show that the carbon content of biomass varies across different vegetation types and this could be attributed to the prevailing conditions such as soil type and climate, as well as the degree of maturity of plants. It was also observed that vegetation types with high above-ground biomass density emitted high amounts of carbon into the atmosphere. This could be attributed to the fact that carbon emission is highly dependent on the fraction of dead and live biomass at the time of burning. Additionally, the class of vegetation with high biomass density contained a higher percentage of dead biomass per hectare than those with low biomass density. Also, Figure 6 shows that a higher level of carbon emission was recorded from one hectare of burnt OSW vegetation when compared with the other vegetation types.

\subsection{Relationship Between Biomass Density and Total Carbon Released}

According to Chuvieco et al. (2008), gaseous emission from the burning biomass of a given vegetation type is directly proportional to the area of vegetation burnt. This observation also applies to this study, given that biomass density and total carbon emitted have a significantly strong positive correlation of $r=0.70$ and $\mathrm{p}=0.001$ (Figure 7). This implies that biomass density increases with an increase in total carbon and vice versa.

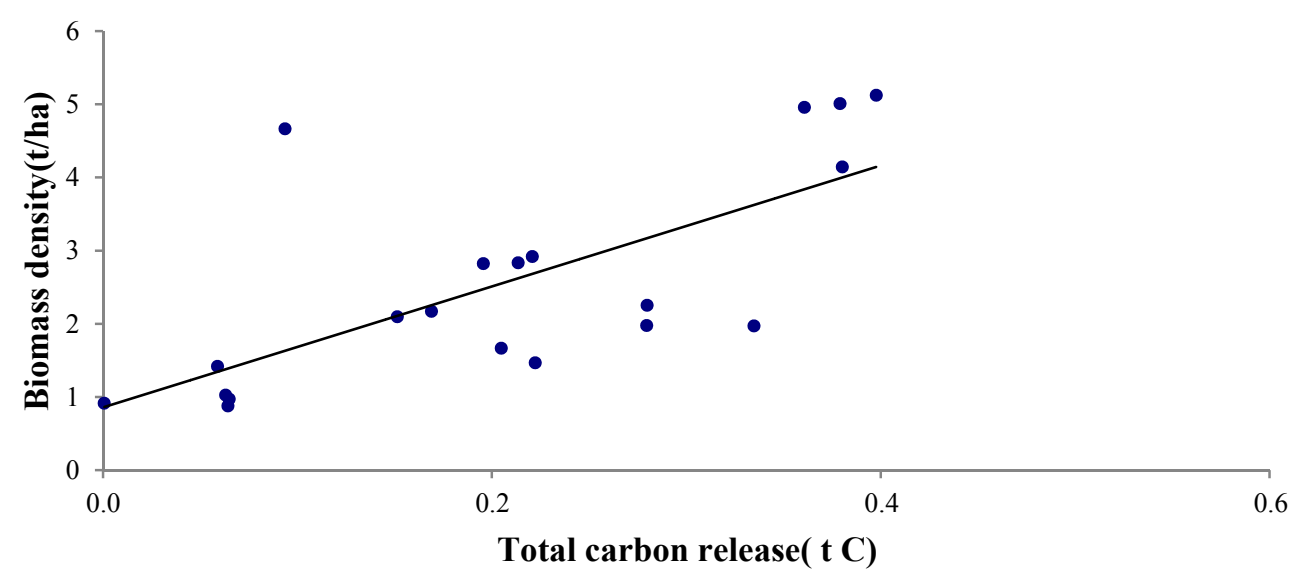

Figure 7. Correlation between above-ground biomass density and total carbon release 


\subsection{Trace Gas Emission From Biomas Burning}

Table 1 shows that, on the average, more $\mathrm{CO}$ is emitted compared with $\mathrm{CH}_{4}$ during savanna wild fires. This is consistent with the results of a similar study by Saarnak et al. (2003) and Bagamsah (2005). This difference in the emission of $\mathrm{CH}_{4}$ and $\mathrm{CO}$ is a result of the difference in the emission ratios applied to $\mathrm{CH}_{4}$ and $\mathrm{CO}$, which were significantly $(\mathrm{P}<0.05)$ different across the four vegetation types, with OSW recording the highest emissions per hectare of burnt land, amounting to $0.001719 \mathrm{t} / \mathrm{ha}$ and $0.045119 \mathrm{t} / \mathrm{ha}$ respectively, while CSW recorded the least emission of $0.000268 \mathrm{t} / \mathrm{ha}$ and $0.007043 \mathrm{t} / \mathrm{ha}$ of $\mathrm{CH}_{4}$ and $\mathrm{CO}$ respectively. The emissions from $\mathrm{CH}_{4}$ and $\mathrm{CO}$ differ significantly $(\mathrm{p}<0.05)$ for all vegetation cover types and were perfectly correlated $(\mathrm{R}=1.00)$ with the quantity of above-ground biomass density and carbon emitted.

The results obtained on estimated emission values (Table 1) from the selected types of vegetation cover in northern Ghana were lower than the results obtained by Saarnak et al. (2003) and Bagamsah (2005). The difference could be linked to variation in above-ground biomass of the different test plots used in the studies, and this may be attributed to a reduction in biomass density within the study area in the previous two and half decades. There is a possibility that, over time, the accumulation of these emissions could increase their atmospheric concentration. In the short term, this could reduce visibility and cause health problems such as an increase in respiratory ailments and human mortality (Levine, 1991; Beer \& Meyer 2000; Johnston et al., 2002; Bagamsah, 2005; Shindell et al. 2009). In the long term, it could contribute to global warming and climate change, since $\mathrm{CO}$ and $\mathrm{CH}_{4}$ have a higher global warming potential compared with $\mathrm{CO}_{2}$ (Rufus \& Kirk, 2002; IPCC, 2007).

Table 1. $\mathrm{CH}_{4}$ and $\mathrm{CO}$ gases emitted per hectare of burnt area (Mean values with Variance in Parenthesis)

\begin{tabular}{ccc}
\hline Vegetation Cover & Emitted $\mathrm{CH}_{4}($ tons $/$ ha $)$ & Emitted CO (tons/ha) \\
\hline WOSW & $0.001154(1.47 \mathrm{E}-07)$ & $0.030303(0.000101)$ \\
GHST & $0.001269(4.39 \mathrm{E}-08)$ & $0.033304(3.02 \mathrm{E}-05)$ \\
OSW & $0.001719(4.7 \mathrm{E}-07)$ & $0.045119(0.000324)$ \\
CSW & $0.000268(2.21 \mathrm{E}-08)$ & $0.007043(1.52 \mathrm{E}-05)$ \\
\hline
\end{tabular}

\subsection{Implications of $\mathrm{CH}_{4}$ and $\mathrm{CO}$ Emissions for Global Warming}

Biomass burning is the third largest source of $\mathrm{CH}_{4}$, contributing about $40 \mathrm{Tg} /$ year to the global methane emission rate (IPCC, 2001) and it is increasing at a rate of about 30 to 40 million tonnes per year (Duxbury \& Mosier 1993). Additionally, global CO emissions from biomass burning estimated using remote sensing techniques were $511 \mathrm{Tg}, 565 \mathrm{Tg}$ and $429 \mathrm{Tg}$ for 1997, 1998 and 1999 respectively (Duncan et al., 2003). Research has proven that each of these gases has a different effect on the atmosphere (MacCarty et al., 2007) because they have different absorptive properties and atmospheric lifespan. The global warming potential for $\mathrm{CH}_{4}$ and $\mathrm{CO}$ is 21 and 3 times respectively the global warming potential of $\mathrm{CO}_{2}$ (Rufus et al., 2002; IPCC, 2007), implying that the emission of 1 unit mass of $\mathrm{CH}_{4}$ or $\mathrm{CO}$ has a climate impact equivalent to that of the emission of 21 and 3 units of mass of $\mathrm{CO}_{2}$ over the 100 -year period following these emissions. It is projected that by the year 2030 the world is likely to be $1-2{ }^{\circ} \mathrm{C}$ warmer than today. Given the full range of uncertainties, the range could be from $0.5{ }^{\circ} \mathrm{C}$ to $2.5^{\circ} \mathrm{C}$ (Moss et al., 2000). A number of studies have emphasized the interactive nature of $\mathrm{CH} 4$ and reactive GHGs, and the effects these interactions can have on overall climate change (Fuglestvedt et al., 1996; Daniel \& Solomon, 1998; Kheshgi \& Jain, 1999; Kheshgi et al., 1999; Hayhoe et al., 2000).

Against this background, it can be safely assumed that the increasing atmospheric concentration of $\mathrm{CH}_{4}$ and $\mathrm{CO}$ from sources such as the study area may be a contributing factor to the continued rise in the average global temperature. Therefore, the need for concerted and collective efforts aimed at reducing these sources to the barest minimum through the implementation of concrete measures backed by appropriate policies cannot be overemphasized. It involves the bottom up participation of major stakeholders from community level to policy and decision makers in the government, which can be achieved through massive awareness creation and education. This entails, first and foremost, the design and implementation of relevant national policies. Ghana, in 2006, developed a practical and comprehensive National Wildfire Policy which is expected to encourage the practice of agro-forestry, natural regrowth and reforestation. Also, it emphasized the development of capacities of all stakeholders in bushfire management and the establishment of a district, regional or national bushfire management fund or insurance scheme to ensure effective and sustainable participation of all stakeholders in the 
bushfire management activities. Furthermore, it provides research institutions and other relevant bodies with the required resources to develop appropriate adaptive measures to bushfire management and to support commercial charcoal producers with improved and sustainable methods of wood carbonization (NWP, 2006). These policy strategies are similar to those in other developing countries like Nigeria, Zambia and The Gambia, and have not been fully exploited. Consequently, the intended target has not been met due to implementation flaws.

In contrast, developed countries like the USA, Canada and Australia have made headway in the implementation of their wild fire policies. For example, in the Victoria state of Australia, the many devastating bushfire scenarios led to the introduction of a Bushfire Safety Policy Framework. It consists of strategies that will regulate bushfire management activities. The recommended approaches adopted are effective awareness and education activities through broad-based media campaigns, government and fire agency websites and publications, locally delivered community education programmes, events and activities, a 'bottom up' community capacity building method aimed at skill and network building to enhance communities' ability to plan for and execute their own bushfire safety options, integration of local community fire plans with other municipal fire and emergency management plans, and the use of a national fire danger rating system that informs communities about different levels of forecast fire danger (Lapsley, 2012). Other initiatives by the Australian Government include the passage of the 1999 Environment Protection and Biodiversity Conservation Act, which provide guidelines to state and territory governments, local councils and other authorities such as fire and emergency services, and individuals on the regulations covering bushfire management activities.

Unlike the developing countries, the developed ones are able to make progress in their bushfire policy implementation as a result of the strict legislation and implementation procedures they adhere to. Their policies are mostly dynamic documents that are reactive or receptive to the experiences of stakeholders as they change with time. In most cases, these policies are usually subjected to reviews which are carried out annually. This best practice is advocated in this paper for implementation in developing countries like Ghana, as a national obligation to reduce the country's greenhouse gas footprint, hence global warming.

\section{Conclusions}

This study concludes that the burning of different vegetation types contributes in different ways to the release of carbon and emission of $\mathrm{CH}_{4}$ and $\mathrm{CO}$ gases. The results of this study showed that the emissions of $\mathrm{CH}_{4}$ and $\mathrm{CO}$ differed significantly $(\mathrm{p}<0.05)$ for all vegetation types and were perfectly correlated $(\mathrm{r}=1.00)$ with the quantity of above-ground biomass density and carbon released. More $\mathrm{CO}$ was emitted than $\mathrm{CH}_{4}$ during savanna wild fires across all the vegetation cover, and the main reason for such discrepancies was the emission ratio used. OSW recorded the highest emission per hectare with $0.001719 \mathrm{t} / \mathrm{ha}$ and $0.045119 \mathrm{t} / \mathrm{ha}$ for $\mathrm{CH}_{4}$ and $\mathrm{CO}$ respectively, while CSW recorded the least emission of $0.000268 \mathrm{t} / \mathrm{ha}$ and $0.007043 \mathrm{t} / \mathrm{ha}$ of $\mathrm{CH}_{4}$ and $\mathrm{CO}$ respectively. The estimated above-ground biomass density for the selected vegetation classes ranged from $\sim 1.0 \mathrm{t} / \mathrm{ha}$ to $\sim 4.8 \mathrm{t} / \mathrm{ha}$ but was highest on OSW. The organic carbon content of the vegetation types also ranged from $29.3 \%$ in CSW to $45.5 \%$ in GHST. The total carbon released, of which $\mathrm{CH}_{4}$ and $\mathrm{CO}$ were estimated, ranged from $\sim 0.000624 \mathrm{t} \mathrm{C/}$ ha in OSW to $\sim 0.398 \mathrm{t} \mathrm{C} / \mathrm{ha}$ in CSW. The findings confirmed the results of similar studies conducted within the savanna regions of Africa. By implication, there is the need to project beyond the immediate environment the consequences of such sources of potent greenhouse gas emissions, in order to ensure that countries like Ghana continue to maintain very minimal contributions to global warming. In order to achieve this objective, the existing flaws in the wild fire management policy of Ghana must be effectively dealt with and appropriately implemented with regular reviews to reduce the annual wild fires, which are rampant in Northern Ghana.

\section{Acknowledgements}

This work was fully funded by the German Federal Ministry of Education and Research (BMBF) through the West Africa Science Center of Climate Change and Adapted Land Use (WASCAL) Master's Research Programme in the Federal University of Technology, Minna, Niger state, Nigeria. We appreciate the technical contributions made by William Attakora (Savanna Agriculture Research Institute, Nyankpala-Tamale), Emmanuel Boakye (Climate Change \& Biodiversity - Universite Felix Houphouet Boigny Ufr Biosciences, Abidjan - Cote d'Ivoire) and Hardi Mohammed (Nyankpala).

\section{References}

Andreae, M. O. (1990). Biomass burning: Its history, use, and distribution and its impact on environmental quality and global climate. In J. Levine (Ed.), Global biomass burning: Atmospheric, climatic, and biospheric implications (pp. 3-21). Cambridge: MIT Press. 
Andreae, M.O. (1997). Emissions of trace gases and aerosols from savanna fires. In B. W. van Wilgen, M. O. Andreae, J. G. Goldammer, \& J. A. Lindesay, (Eds.), Fire in the Southern African Savanna: Ecological and Environmental Perspectives (pp. 161-183). Johannesburg: Witwaters and University Press. Retract from http://www.researchgate.net/publication/44158698_Emissions_of_trace_gases_and_aerosols_from_souther n_African_savanna_fires

Bagamsah, T. T. (2005). The impact of bushfire on carbon and nutrient stocks as well as albedo in the savanna of northern Ghana. Ecology and Development Series, 25. Retrieved from http://books.google.com.gh/books/ about/The_Impact_of_Bushfire_on_Carbon_and_Nut.html?id=Tow-_cMnn48C\&redir_esc $=\mathrm{y}$

Bagamsah, T. T. (2005). The impact of bushfire on carbon and nutrient stocks as well as albedo in the savanna of northern Ghana. Ecology and Development Series (No. 25), 2005. http://books.google.com.gh/books/ about/The_Impact_of_Bushfire_on_Carbon_and_Nut.html?id=Tow-_cMnn48C\&redir_esc $=\mathrm{y}$

Beer, T., \& Meyer, C. P. (2000). The impact on the environment - The atmosphere. In Fire! The Australian experience: Proceedings from the National Academies Forum Seminar (pp. 59-77). National Academies Forum, Canberra, ACT, Australia.

Benscoter, B. W., Thompson, D. F., Waddington, J. M., Flannigan, M. D., Wotton, M., DeGroot, W., \& Turetsky, M. R. (2011). Interactive effects of vegetation, soil moisture, and bulk density on the depth of burning of thick organic soils. International Journal of Wild Land Fire, 20, 418-429. http://dx.doi.org/10. 1071/WF08183

Bolin, B., Degens, E. T., Duvigneaud, P., \& Kempe, S. (Eds.) (1979). The global carbon cycle. SCOPE Report, 13, 1-56. Wiley, Chichester, England.

Bourliére, F., \& Hadley, M. (1983). Present-day savannas: An overview. In F. Bourliére (Ed), Ecosystems of the world (vol. 13, pp. 1-17). Tropical Savannas. Amsterdam: Elsevier.

Bucini, G., \& Lambin, E. F. (2002). Fire impacts on vegetation in Central Africa: a remote-sensing-based statistical analysis. Applied Geography, 22(1), 27-48. http://dx.doi.org/10.1016/S0143-6228(01)00020-0

Cahoon, D. R., Stocks, B. J., Levine, J. S., Coffer III, W. R., \& O’ Neil, K. P. (1992). Seasonal distribution of African savanna fires. Nature, 359, 812-815. http://dx.doi.org/10.1038/359812a0

Chuvieco, E., Giglio, L., \& Justice, C. (2008). Global characterization of fire activity: toward defining fire regimes from earth observation data. Glob. Chang. Biol., 14, 1488-1502. Retrieved from http://onlinelibrary.wiley.com/doi/10.1111/j.1365-2486.2008.01585.x/pdf

Cobbina, S. J., Armah, F. A., \& Obiri, S. (2011). Multivariate Statistical and Spatial Assessment of Groundwater Quality in the Tolon-Kumbungu District, Ghana. Research Journal of Environmental and Earth Sciences, 4(1), 88-98. Retrieved from www.sciencepub.net/newyork/ny0611/006_21356ny0611_38_48.pdf

Crutzen, P. J., \& Andreae, M. O. (1990). Biomass Burning in the Tropics: Impact on Atmospheric Chemistry and Biogeochemical Cycles. Science, 250(4988), 1669-1678. http://dx.doi.org/10.1126/science.250. 4988.1669

Daniel, J. S., \& Solomon, S. (1998). On the climate forcing of carbon monoxide. Journal of Geophysical Research: Atmospheres (1984-2012), 103(D11), 13249-13260. http://onlinelibrary.wiley.com/doi/10.1029/ 98JD00822/abstract

Dansereau, P. (1951). Description and recording of vegetation upon a structural basis. Ecology, 32, 172-229. http://dx.doi.org/10.2307/1930415

Danthu, P., Ndongo, M., Diaou, M., Thiam, O., Sarr, A., Dedhiou, B., \& Vall, A. O. M. (2003). Impact of bush fire on germination of some West African Acacias. Forest Ecology and Management, 173, 1-10. http://dx.doi.org/10.1016/S0378-1127(01)00822-2

Duncan, B. N., Martin, R. V., Staudt, A. C., Yevich, R., \& Logan, J. A. (2003). Inter-annual and 25 seasonal variability of biomass burning emissions constrained by satellite observations. J. Geophys. Res., 108(D12), 4100. http://dx.doi.org/10.1029/2002JD002378

Duxbury J. M., \& Mosier, A. R. (1993). Status and issues concerning agricultural emissions of greenhouse gases. In: Kaiser H.M., Drennen, T.W. (Eds), Agricultural Dimensions of Global Climate Change (pp. 229-258). Delray Beach, FL: St. Lucie Press. http://onlinelibrary.wiley.com/doi/10.1002/sd.3460020305/abstract

FAO. (1988). Soil Map of the World. Revised Legend. World Soil Resources Report 60. FAO-UNESCO, Rome, $119 \mathrm{pp}$. 
Fuglestvedt, J. S., Isaksen, I. S. A., \& Wang, W. C. (1996). Estimates of indirect global warming potentials from $\mathrm{CH}_{4}, \mathrm{CO}$, and $\mathrm{NO}_{x}$. Climate Change, 34, 405-437. http://dx.doi.org/10.1007/BF00139300

GSS (Ghana Statistical Service). (2010). Ghana Population and Housing Census, 2010. http://www.statsghana.gov.gh/

Hao, W. M., \& Liu, M. H. (1994). Spatial and temporal distribution of tropical biomass burning. Global Biogeochem. Cy., 8, 495-503. http://onlinelibrary.wiley.com/doi/10.1029/94GB02086/abstract

Hao, W. M., Liu, M., \& Crutzen, P. J. (1990). Estimates of annual and regional releases of $\mathrm{CO}_{2}$ and other trace gases to the atmosphere from fires in the tropics, based on the FAO statistics for the period 1975-1980. In: Goldammer, J.G. (Ed), Fire in the tropical biota: ecosystem processes and global challenges (pp. 440-462). Springer- Verlag, Berlin. http://link.springer.com/book/10.1007\%2F978-3-642-75395-4

Hayhoe, K., Jain, A., Kheshgi, H. S., \& Wuebbles, D. (2000). Contribution of $\mathrm{CH}_{4}$ to multi-gas reduction targets: The impact of atmospheric chemistry on GWPs. In J. van Ham (Ed.), Non-CO ${ }_{2}$ Greenhouse Gases: Scientific Understanding, Control and Implementation (pp. 425-432). New York: Springer. http://dx.doi.org/10.1007/978-94-015-9343-4_67

Intergovernmental Panel on Climate Change (IPCC). (2001). Climate Change 2001, Working Group I: The Scientific Basis. In J. T. Houghton, Y. Ding, \& D. J. Griggs (Eds.). Cambridge: Cambridge University Press.

IPCC. (1996). Greenhouse Gas Inventory. Reference Manual, Workbook. Revised 1996 IPCC Guidelines for National Greenhouse Gas Inventories.

Jain, A. K., Tao, Z., Yang, X., \& Gillespie, C. (2006). Estimates of global biomass burning emissions for reactive greenhouse gases (CO, NMHCs, and $\left.\mathrm{NO}_{\mathrm{x}}\right)$ and $\mathrm{CO}_{2} . \quad J$. Geophys. Res., 111 . http://dx.doi.org/10.1029/2005JD006237

Johnston, F. H., Kavanagh, A. M., Bowman, D. M. J. S., \& Scott, R. K. (2002). Exposure to bushfire smoke and asthma: an ecological study. Medical Journal of Australia, 176, 535-538. Retrieved from http://www.climate.atmos.uiuc.edu/atuljain/publications/2005JD006237.pdf

Jones, R. (1979). Annu. Rev. Anthropol., 8,445. http://dx.doi.org/10.1146/annurev.an.08.100179.002305

Kheshgi, H. S., Jain, A. K. (1999). Reduction of the atmospheric concentration of methane as a strategic response option to global climate change. In P. Reimer, B. Eliasson, \& A. Wakaun (Eds.), Greenhouse Gas Control Technologies (pp. 775-780). New York: Elsevier.

Kheshgi, H. S., Jain, A. K., Kotamarthi, V. R., \& Wuebbles, D. J. (1999). Future atmospheric methane concentrations in the context of the stabilization of greenhouse gas concentrations. Journal of Geophysical Research: Atmospheres (1984-2012), 104(D16), 19183-19190. Retrieved from http://www.climate.atmos. uiuc.edu/atuljain/publications/1999JD900367.pdf

Korem, A. (1985). Bushfire and Agriculture Development in Ghana. Tema, Ghana Publishing Cooperation, 220.

Korontzi, S., Justice, C. O., \& Scholes, R. J. (2003). Influence of timing and spatial extent of savanna fires in southern Africa on atmospheric emissions. $J$ Arid Environ, 54, 395-404. http://dx.doi.org/10.1006/jare.2002. 1098

Kugbe, J. (2012). Spatio-temporal dynamics of bush-fire nutrient losses and atmospheric depositional gains across the northern savanna region of Ghana. PhD Dissertation, Faculty of Agriculture, University of Bonn. Issue 90 of Ecology and Development Series. Retrieved from http://www.hss.ulb.uni-bonn.de/2012/3006/ 3006.pdf

Lacaux, J. P., Cachier, H., \& Delmas, R. (1993). Biomass burning in Africa: An overview of its impact on atmospheric chemistry. In Fire in the Environment.

Langaas, S. (1995). Night-Time Observations of West Africa Bushfires from Space. Studies on Methods and Application of Thermal NOAA/AVHRR Satellite Data from Senegal and the Gambia. Thesis / Dissertation, Department of Geography, University of Oslo, Norway.

Lapsley, C. (2012). Bushfire Safety Policy Framework. Fire Services Commission, Victoria State - Australia. Retrieved from http://fire-com-live-wp.s3.amazonaws.com/wp-content/uploads/2013-Bushfire-Safety -Policy-Framework.pdf 
Laris, P. (2002). Burning the seasonal mosaic: preventive burning strategies in the wooded savanna of southern Mali. Human Ecology, 30, 155-186. http://dx.doi.org/10.1023/A:1015685529180

Lawson, G. W. (1985). Plant Life in West Africa. Accra: Ghana Universities Press.

Levine, J. S. (1991). Global Biomass Burning: atmospheric, climatic, and biospheric implications. Massachusetts: MIT Press. Retrieved from http://onlinelibrary.wiley.com/doi/10.1029/90EO00289/pdf

MacCarty, N., Ogle, D., Still, D., Bond, T., Roden, C., \& Willson, B. (2007). Laboratory comparison of the global-warming potential of six categories of biomass cooking stoves. Aprovecho Research Center, Advanced study in appropriate technology laboratory. Retrieved from http://scscertified.com/lcs/docs/ Global_warming_full_9-6-07.pdf

Martin, A. R., \& Thomas, S. (2011). A reassessment of carbon content in tropical trees, PLoS One, 6, e23533:1e23533:9. http://journals.plos.org/plosone/article?id=10.1371/journal.pone.0023533.

Mbow, C., Nielsen, T. T., \& Rasmussen, K. (2000). Savanna fires in east-central Senegal: Distribution patterns, resource management and perceptions. Human Ecology, 28(4), 561-583. http://dx.doi.org/10.1023/A:10264 87730947

Mbow, C., Nielsen, T. T., \& Rasmussen, K. (2000). Savannah fires in east-central Senegal: distribution patterns, resource management and perceptions. Human Ecology, 28(4), 561-583. http://dx.doi.org/10.1023/A:102 6487730947

Melson, S. L., Harmon, M. E., Fried, J. S., \& Domingo, J. B. (2011). Estimates of live-tree carbon stores in the Pacific Northwest is sensitive to model selection. Carbon Balance Manag., 6, 1-16. http://dx.doi.org/ 10.1186/1750-0680-6-2

Menaut, J. C., Abbadie, L., Lavenu, F., Loudjani, P., \& Podaire, A. (1991). Biomass burning in West African savannas. In S. J. Levine (Ed.), Global Biomass Burning: Atmospheric, Climatic, and Biospheric Implications (pp. 133-142). Cambridge: MIT Press.

Menz, M., \& Bethke, M. (2000). Vegetation map of Ghana. Regionalization of the IGBP Global Land Cover Map for Western Africa (Ghana, Togo and Benin). In Proceedings of the 20th EARSeL-Symposium. June 2000, Dresden, in press. Remote Sensing Research Group. Institute of Geography. University of Bonn, Germany.

Middelmann, M. H. (Ed.) (2007). Natural Hazards in Australia. Identifying Risk Analysis Requirements. Geoscience Australia, Canberra.

Moss, A. R., Jouany, J., \& Newbold, J. (2000). Methane Production By Ruminants: Its Contribution To Global Warming. Ann. Zootech., 49, 231-253. INRA, EDP Sciences. Retrieved from http://animres. edpsciences.org/articles/animres/abs/2000/03/z0305/z0305.html

NWP. (2006). National wildfire policy, Ghana. Retrieved from http://www.rspo-in-ghana.org/sitescene/custom/ userfiles/file/national_wildlife_management_policy.pdf_on

Reid, R. S., Kruska, R. L., Muthui, N., Taye, A., Wotton, S., Wilson, C. J., \& Mulatu, W. (2000). Land-use and Land-cover dynamics in response to changes in climatic, biological and socio-political forces: the case of South western Ethiopia. Landscape Ecology, 15, 339-355. http://dx.doi.org/10.1023/A:1008177712995

Rudolph, J., Khedim, A., Koppmann, R., \& Bonsang, B. (1995). Field study of the emissions of methyl chloride and other halocarbons from biomass burning in western Africa, J. Atmos. Chem., 22, 67-80. http://dx.doi.org/10.1007/BF00708182

Rufus, D. E., \& Kirk, R. S. (2002). Carbon Balances, Global Warming Commitments, and Health Implications of Avoidable Emissions from Residential Energy Use in China: Evidence from an Emissions Database. http://www.giss.nasa.gov/meetings/pollution2002/d3_edwards.html

Saarnak, C. F., Nielsen, T. T., \& Mbow, C. (2003). Local study on the Trace Gas Emissions from Vegetation Burning Around the Village of Dalun-Ghana with respect to Seasonal Vegetation Changes and Burning Practices. Climatic Change, 56, 321-338. http://dx.doi.org/10.1023/A:1021788509191

Saner, P., Loh, Y. Y., Ong, R. C., \& Hector, A. (2012). Carbon stocks and fluxes in tropical lowland Dipterocarp rainforests in Sabah, Malaysian Borneo. PLoS ONE, 7, e29642:1-e29642:11. http://journals.plos.org/ plosone/article?id=10.1371/journal.pone.0029642 
Schils, R., Kuikman, P., Liski, J., van Oijen, M., Smith, P., Webb, J., ... Hiederer, R. (2008). Review of existing information on the interrelations between soil and climate change. CLIMSOIL. European Communities. $\mathrm{http}: / /$ ec.europa.eu/environment/soil/review_en.htm

Schlesinger, W. H. (1991). Biogeochemistry, an Analysis of Global Change. New York: Academic Press. http://www.sciencedirect.com/science/book/9780126251579

Shea, R. W., Shea, B. W., Kauffman, J. B., Ward, D. E., Haskins, C. I., \& Scholes, M. C. (1996). Fuel biomass and combustion factors associated with fires in savanna ecosystems of South Africa and Zambia. Journal of Geophysical Research: Atmospheres (1984-2012), 101(D19), 23551-23568. http://onlinelibrary.wiley.com/ doi/10.1029/95JD02047/abstract

Shimada, S., Takahashi, H., Kaneko, M., \& Haraguchi, A. (1999, November). The estimation of carbon resource in a tropical peatland: a case study in Central Kalimantan, Indonesia. In Proceedings of the International Symposium on Tropical Peatlands, Bogor, Indonesia (pp. 9-18).

Shindell, D. T., Faluvegi, G., Koch, D. M., Schmidt, G. A., Unger, N., \& Bauer, S. E. (2009). Improved attribution of climate forcing to emissions. Science, 326, 716-718. http://dx.doi.org/10.1126/ science. 1174760

Stott, P. (1994). Savanna landscapes and global environmental change. In N. Roberts (Ed), the Changing Global Environment (pp. 287-303). Cambridge: Blackwell.

Thomas, S. C., \& Malczewski, G., (2007). Wood carbon content of tree species in eastern China: Interspecific variability and the importance of the volatile fraction. J. Environmental Management, 85, 659-662. http://dx.doi.org/10.1016/j.jenvman.2006.04.022

Trollope, W. S. W., \& Trollope, L. A. (1996). Fire in African savanna and other grazing ecosystems. Paper presented at the seminar on 'Forest fire and Global Change', held in Shushenkoye in the Russian Federation from 4th-10th August 1996.

UNFCCC. (1992). United Nations Framework Convention on Climate Change. Climate Change Secretariat, Geneva, June.

van der Werf, G. R., Randerson, J. T., Giglio, L., Collatz, G. J., Mu, M., Kasibhatla, P. S., ... \& van Leeuwen, T. T. (2010). Global fire emissions and the contribution of deforestation, savanna, forest, agricultural, and peat fires (1997-2009). Atmospheric Chemistry and Physics, 10(23), 11707-11735. http://dx.doi.org/10.5194/ acp-10-11707-2010

Wills, J. B. (1962). Agriculture and land use in Ghana, Ghana Ministry of Food and Agriculture. London: Oxford University Press. http://www.mofa.gov.gh/site/wp.../10/AGRICULTURE-IN-GHANA-FF-2010.pdf

Wuver A. M., Attuquayefio, D. K., \& Enu-Kwesi, L. (2003). A study of bushfires in Ghanaian coastal wetland. II. Impact on floral diversity and soil seed bank. West African Journal of Applied Ecology, 4. 2003. Retrieved from www.ajol.info/index.php/wajae/article/viewFile/45583/29066

Zhang, X., \& Kondragunta, S. (2008). Temporal and spatial variability in biomass burned areas across the USA derived from the GOES fire product. Remote Sensing of Environment, 112, 2886-2897. Elsevier Inc. Retrieved from http://www.goes-r.gov/resources/.../1-s2.0-S0034425708000576-main.pdf

\section{Copyrights}

Copyright for this article is retained by the author(s), with first publication rights granted to the journal.

This is an open-access article distributed under the terms and conditions of the Creative Commons Attribution license (http://creativecommons.org/licenses/by/3.0/). 